\title{
Consumers’ Perceptual Biasness in Debit Cards of Indian Banks
}

\section{Prasad S*}

Associate Professor in Marketing, Regional College of Management, Bhubaneswar, India

\begin{abstract}
Debit cards are highly attractive to convenience driven consumer markets. As banks explore potential debit based loyalty system therefore convenience and control seeking consumers found debit cards as more attractive option. This card business depends on very reliable and secure technology and requires a very strong connectivity backbone. The topic taken for the research is a recent issue related to the debit card and the preference of customers towards different types of debit cards of different banks. Primary data has been collected through questionnaire of sample taken from the market which is a replica of the universe (Population of India). By the primary data the profile of customer being selected which are highly affected by the utility of the debit card. Hence the research justifies that the factors responsible for selecting a debit card are favourability, situational, recognize and bias. MDS (Multi-dimensional scaling) technique has been taken to study the perception of the customer for different brands of debit cards especially the public sector and private sector banks. The study has given an idea about the high inclination of customers towards private sectors debit cards than public sectors one.
\end{abstract}

Keywords: Consumer; Perceptual biasness; Debit cards; Multidimensional scaling; Indian banks

\section{Introduction}

Indian financial institutions like banking is the lifeline of the nation has helped in developing the major sectors of the economy and usher in a new dawn of progress on the Indian economy. The sector has created the hopes and aspirations of millions of people into reality in the world. But it has control the miles of difficult terrain and suffers under the foreign rules and the pangs of partition. Recently Indian banks have adopted the modern technology and can strongly compete with modern banks of the world [1]. The economic reforms of have presented a challenge before Indian banking sector to make continuous innovation with the pace of new technological change. The technological advancement and adoption is purely based on the consumers' acceptance and positive response. Traditionally, banks were only concerned with the stereotyped activities like acceptance of deposits and lending surplus money to the customer at some rate of interest and the common products being availed by banks were savings account, current account, term deposit account and lending products like cash credit and term loans. It becomes very much necessary for the today's banks to offer the services by taking into account the customer's needs, preferences, perceptions and convenience [2]. Customer is now enjoying the facilities of banks like anywhere, anytime banking. Internet banking has changed the bank market dramatically. Innovative banking services like plastic cards introduced in the market which has changed the customer lifestyle by making them more dynamic. Today's customer mostly made the transactions through plastic cards and most preferably the highly acceptable debit cards. Consumers are trying to code, categorize and evaluate economic outcomes and frame the transaction which determines the benefits and the level of satisfaction they expect to receive [3]. The process of payment mode serves to influence outcome perceptions of the customers.

Electronic banking has a wider scope which has adopted by the banking sector now days. Banks have developed various sophisticated products to meet the basic requirements of their customers. Indian banking sector has faced a dramatic change with the advent of tech savvy private sector banks and foreign banks. Public sector banks have created a large network of traditional branches to approach their customers from urban to rural as compared to the private and foreign players. Information technology has made a revolutionary to deliver the banking products and services efficiently and effectively. The new private and foreign bankers on the basis of adoption of new technological services like plastic cards, personal computer banking, electronic funds transfer, internet banking can able to connect maximum number of customers in spite of having less physical presence. Now public sector banks are equally trying to move towards electronic banking, which leads to the remarkable development with respect to its operational efficiency, customer services, employee productivity and banking profitability. Now banks are bringing flexibility in their distribution channel by reengineering their services.

There is a rising acceptance of debit cards in retail locations which has increased the debit cards transactions. Highest number of consumers and merchants acceptance of plastic cards has changed the way to move beyond the traditionally geographic located merchant base to modern arena of transactions. The demand for debit cards has grown rapidly among consumers as these are more convenient than other payment options and cost effective for merchants. Consumers with the limited access to existing payment methods find a debit card is the most suitable instrument for the latest transactions. Debit cards' superiority over credit cards as the most acceptable form of electronic payment at the point of sale and it becomes a primary consumer choice which requires relatively little scrutiny for acceptance. Debit card users who have the knowledge of hidden cost associated with the credit cards are rationally choose to use debit card to minimize the transaction costs. The drawbacks like binding limit in credit cards are converting customers to rely more on debit cards.

\section{Objectives}

Debit card plays a vital role in plastic cards which has changed the

${ }^{*}$ Corresponding author: Saraju Prasad, Associate Professor in Marketing Regional College of Management, Bhubaneswar, Odisha-751023, India, Tel: 9090080822; E-mail: saraju_prasad@rediffmail.com

Received April 11, 2016; Accepted May 05, 2016; Published May 15, 2016

Citation: Prasad S (2016) Consumers' Perceptual Biasness in Debit Cards of Indian Banks. J Bus Fin Aff 5: 186. doi:10.4172/2167-0234.1000186

Copyright: @ 2016 Prasad S. This is an open-access article distributed under the terms of the Creative Commons Attribution License, which permits unrestricted use, distribution, and reproduction in any medium, provided the original author and source are credited. 
future of banking sector and positioned as a multiple service provider instruments for the consumer. It can able to change the perception of both customers and merchant by reducing the complexities in the financial transactions and became a strong instrument in banking operations. Keeping in view of the above discussion the present study has made an attempt to study the profile of customers using debit cards different banks. Also the study gives idea about the factors creates biasness to select the debit cards of any banks and the customers' perception about the different brands of debit cards.

\section{Methodology}

The research design is mostly based on the consumers' decision on different debit cards on the basis of banks like public and private sectors. For literature review articles are mostly taken from published journal of e-journal sites. Sampling methods used for this research is stratified sampling one (respondents mostly in the twin city Bhubaneswar and Cuttack of Odisha i,e. an state in Eastern India). Questionnaire method was used to collect the data from the market from 400 respondents during the period of January to February 2016. Pilot survey has been conducted to know the acceptance of debit cards of different banks and their relative importance for the customers. Considering the feedback of the respondents questionnaires are being designed to apply different statistical tools for inference. Statistical tools like factor analysis and multi-dimensional scaling techniques are used to interpret the data by data analysis through the statistical software SPSS.

\section{Literature Review}

Customer perceives that private sector banks provide better services in terms of facilities than the public sector banks. Although public sector banks have a strong presence in terms of branches in the market, but now days they are facing stiff competition from private sector banks in terms of quality of services they offered [4]. High level of customers' adoption of online banking systems because of perceived usefulness, ease of use, awareness of technology and less perceives risks on customer to accept online banking system [5]. Extending technology driven products for farmers will enhance the brand image of commercial banks and helps to enlarge the base of operation to attract more farmers to commercial banks [6]. Adoption of new technological in banks are always assets to a bank which will reduces the cost in long runs like years of operation of the technology, urban location, deposits ratio and expenses ratio [7]. Internet banking has become an important medium to sell the products and services of banks to stay profitable and successful [8]. Domestic and foreign banks are providing five basic services associated with internet banking like to view account balances and transaction histories, paying bills, transferring funds within accounts, requesting for credit card advances and ordering checks quickly [9]. Now days customers' can able to do anytime and anywhere banking through internet banking services provided by the banks through their websites [10]. With the advent of new technologies in banking sectors consumers' can able to do e-banking through the internet services and applications in mobile phones. The main motivation factors for the consumers to use internet banking are the speed, the convenience of remote access, seven days and twenty four hours availability of services and the price incentives [11]. The easier accessibilities of the banking products and services facilitates the adoption of internet banking by consumers [12]. The services offered by the banks like internet banking, automated tailor machine (ATM) and phone banking are substitute to each other [13]. Consumer will prefer highly to a particular types of internet banking services where the consumer familiarity is highest [14]. Clients' usage rate of banking products and services through internet banking depends upon the attitude customers' towards it [15].
Consumers' influenced towards internet banking through document accessibility of internet, awareness of e-banking and resistance to change. Sellers' support plays a vital role on clients' usage of internet banking [16]. All the financial institutions has accepted that smart card technology as a viable retail point of sale transactional alternative and a right replacements for cash in everyday exchange situations around the world [17].

Credit card is right kind of plastic card for those customers who use it to increase their purchasing power [18]. Plastic cards of different banks provide new packages to attract the customers like tele-ticketing, offers, insurance coverage and reward points etc. Debit cards penetrate very rapidly in the consumers' market while Rysman clarified through his research that demographic variables have high impact on consumer choice for any brand of credit cards $[19,20]$. Hayashi, Sullivan and Weiner (2003) examined that consumers have given equal importance on adoption of debit cards as well as direct deposit and electronic bill payment [21]. Credit card holders are influenced more by the informal sources than the mass media and are using credit cards because of ease of payment and risk of carrying cash [22]. Older adults use credit cards with similar frequency to younger adults when circumstances and opportunities for consumption in both the groups are similar [23]. Lots of factors are responsible for the growing demand of plastic cards like rapid expansion, increasing acquisitive middle class, growing demand of expenses towards travel and entertainment, sophisticated merchant establishment and more transparency in financial system [24]. There is an increase usage of credit cards in developing countries because of increased level of socio-economic and technological development [25].

In twenty first century plastic cards as an efficient electronic payment system changed the market into a cashless society by reducing the transactions through coins and notes [26]. The changing utility of the smart card can be able to deal with the transaction of non-financial data which has changed the purchase system through collection and exchange [27]. This change affected the retailers through their store and office upgradation, replacement of point of sales terminals and giving training to the cashiers which has indirectly created a substantial cost to accept the smart cards. The latest features of plastic card like pay later, pay now and pay before has created future prospects by the development of the cashless society [28]. The authorization system quality can be measured through two major considerations like the enhancement of customer's quality service by reducing the waiting time at the point of sale and by reducing the risk of bad credit transactions [29]. Any banks credit and money supply can be controlled through the amount of credit have given to individuals as well as households [30]. There is a negative relationship exist between the usage of consumer's bankcard and store cards during transaction as store cards plays a substitute of bank cards [31]. The evidence of credit cards explosive growth in numbers and amount of transactions indicates the benefits derived by the customers and merchants [32]. Consumers considers few factors like income level, fees for service network, add on card facility availability, revolving credit facility, insurance facilities, cash withdrawal charges, lost card liabilities for selecting the best credit card provider [33]. Consumer perceived now days that credit card is the convenient substitute for carrying cash and a right kind of credit facilities for a short period [34].

The advent of innovations in information and communication technology has changed the usage of credit card which indirectly encourages the customer for compulsive buying [35]. These cards have changed the horizon with various features like identity proof, storage for bank data, e-purse, finger print, health record, blood group and license details of each individual [36]. Worthington et al. Customers 
feel comfortable to hold and use of the credit cards for spending on travel and entertainment purpose [37]. The multiple cardholders are always feeling comfortable to spend more through a specific credit card called main card which indirectly gives benefit to the card issuer [38]. Customers are willing to use the mobile phone credit card which can able to carry highest amount of information related to transactions [39]. The variations in number of credit card holders depends upon the number of times customers using the cards for the services like number of time missing payments, frequency of use, entertainment expenditures, and petrol purchase [40].

VISA and Master Card both the organizations are responsible for any kind of international payment system and both of them act as franchisers, lending their names to credit and debit cards of respective member banks and act as a guarantor of payment to merchants which will receive the cards [41]. Both VISA and Master card are not credit or debit card companies but functioning for bankers to provide a global network to give authorization, clearing and settlement of card transactions for both credit and debit cards. Less educated, lower income groups, middle-aged and owner of fewer credit cards are mostly using the cash transactions [19]. In other way debit and credit card users are mostly younger, highly educated and holds more numbers of credit or debit cards. The rising interest of customers towards debit cards is because of combination of factors like ease of availability of cards, profile of customer inclined towards debit averse and zero interest rates on cards [42]. Todays' competitive market customers are financially so much sophisticated and eager to use the latest technology plastic card like debit cards to avoid interest due to credit cards which shows that the amount of spending is more on credit cards but the number of transactions is more on debit cards [43]. The emerging trend in India shows a greater importance of debit card in daily lives which capture the market in places like supermarkets, petrol stations, convenience stores where most transactions are done by cashes or cheques in earlier days [44]. The high acceptability of debit cards with comparison to credit cards is because of few factors like assurance of payments to retailers, use interest free period to avoid high interest cost, reduce annual charges, easy electronic fund transfer,

\begin{tabular}{|c|c|c|c|}
\hline Particular & Category & Frequency & Percentage \\
\hline \multicolumn{4}{|c|}{ Annual Income in Rs. } \\
\hline & Less than 5 Lac & 16 & 4 \\
\hline & $5 \mathrm{Lac}$ to $8 \mathrm{Lac}$ & 26 & 6.5 \\
\hline & $8 \mathrm{Lac}$ to $10 \mathrm{Lac}$ & 122 & 30.5 \\
\hline & 10Lac above & 236 & 59 \\
\hline \multicolumn{4}{|l|}{ Age } \\
\hline & $20-25$ & 15 & 3.75 \\
\hline & $25-30$ & 77 & 19.25 \\
\hline & $30-35$ & 104 & 26 \\
\hline & $35-40$ & 204 & 51 \\
\hline \multicolumn{4}{|l|}{ Occupation } \\
\hline & Student & 11 & 2.75 \\
\hline & Salaried Employee & 124 & 31 \\
\hline & Businessman & 145 & 36.25 \\
\hline & Professional & 120 & 30 \\
\hline \multicolumn{4}{|c|}{ Family size $(2+)$} \\
\hline & Bachelor & 15 & 3.75 \\
\hline & Married with no kid & 72 & 18 \\
\hline & Married with one kid & 168 & 42 \\
\hline & Married with two kids & 145 & 36.25 \\
\hline
\end{tabular}

Table 1: Demographic profile of respondents. point of services offer a huge acceptance of debit cards, cutting down the cost associated with the paper based clearing and payment services [45]. Information and technology has given a great change on Indian banking sector for their survival and growth in the advancements of plastic cards which has the bright future prospects of e-payments market in India [46]. Manivannan In the entry level debit cards are used only by higher income groups residing in urban areas or cities but now it has widely accepted to fixed income groups or salaried classes and also the customers staying in rural areas [47].

\section{Results and Analysis}

\section{Demographic profile}

The respondents selected for the debit card holders are mostly income level above Rs.10 Lacs (59\%) followed by Rs.8 to 10 Lacs (30\%). $77 \%$ of the total respondents are in the age group of 30 to 40 year. There is almost equi-proportionate of salaried employees, professionals and businessman and around $78 \%$ of them are married and having one or two kids (Table 1).

\section{Different brands of debit cards}

Out of 400 respondents, $39.5 \%$ and $13.5 \%$ of respondents are using debit cards exclusively and $46.5 \%$ are both from private and public sector banks. $36.25 \%$ of respondents are using the Industrial Credit and Investment Corporation of India (ICICI) a private sector bank followed by $26 \%$ by Housing Development Financial Corporation (HDFC) a private sector bank shown in Table 2.

\section{Factor analysis}

This research focused mostly to the customer perception towards selecting a debit card. Several statements are generated from the variables to measure attitude of the respondents on a 5-point Likert scale. These scores are measured though the factor analysis to know the utility of each factors.

Table 3 depicts the variables under each of the four desired factors. The first factor 'favorability' identified with acceptance, high level of discounts in brand of debit card, transaction in ATM (Automated Tailored Machine), discounts on the basis of point system and international transaction. The second factor 'situational' explains the selection of a brand of debit card depends upon number of ATMs and distance of ATM from residence. The third factor 'recognize' explains the cash back reward system and unlimited transactions. The fourth factor 'bias' explains the debit card is selected because of influence of family and most popular bank.

Ranking has made on the basis of highest factor loadings generated by the different factors. In the Table 4 customers have given highest factor loading score to the factor like 'favorability' followed by 'situational,' 'recognize' and 'bias' respectively.

\begin{tabular}{|c|c|c|}
\hline Banks & Frequency & Percentage \\
\hline Private Sector & 158 & 39.5 \\
\hline Public Sector & 55 & 13.75 \\
\hline Both & 187 & 46.75 \\
\hline Debit Cards of different banks & & \\
\hline ICICI(Private Sector) & 145 & 36.25 \\
\hline HDFC(Private Sector) & 96 & 24 \\
\hline SBI(Public Sector) & 89 & 22.25 \\
\hline PNB(Public Sector) & 35 & 8.75 \\
\hline Others(both Public and Private) & 35 & 8.75 \\
\hline
\end{tabular}

Table 2: Profile of respondents using different brands of debit cards. 


\begin{tabular}{|c|c|}
\hline \multirow{5}{*}{ Favorability F1 } & Most of the transaction this brand of debit card is highly acceptable (S3) \\
\hline & High level of discounts can be available in this brand of debit card (S4) \\
\hline & Transaction in ATM (Automated Tailored Machine) is quite safety (S5) \\
\hline & Discount can be available on the basis of point system available in the debit card. (S6) \\
\hline & Any international transaction can be possible through this debit card (S7) \\
\hline \multirow{3}{*}{ Situational F2 } & Selection of a brand of debit card depends upon the number of ATM branches (S1) \\
\hline & Selection of a brand of debit card depends on the distance of ATM from \\
\hline & Residence (S2) \\
\hline \multirow{2}{*}{ Recognize F3 } & Cash back reward system available with this debit card (S10) \\
\hline & Unlimited transaction can be possible through other banks ATMs (S11) \\
\hline \multirow{2}{*}{ Bias F4 } & You select the debit card because of the influence of family or relatives (S8) \\
\hline & You select the debit card because of most popular bank (S9) \\
\hline
\end{tabular}

Table 3: Factors generated through the variables of debit card.

\begin{tabular}{|c|c|c|}
\hline Factors & $\begin{array}{c}\text { Factor loadings of each } \\
\text { factor }\end{array}$ & $\begin{array}{c}\text { Ranking on basis of } \\
\text { score }\end{array}$ \\
\hline F1(Favorability) & 3.351 & 1 \\
\hline F2(Situational) & 1.759 & 2 \\
\hline F3(Recognize) & 1.622 & 3 \\
\hline F4(Bias) & 1.426 & 4 \\
\hline
\end{tabular}

Table 4: Ranking of factors on high factor loads.

\section{Multi-dimensional scaling (MDS)}

The result of the multidimensional scaling in terms of stress value is 0.15 which is acceptable and the $\mathrm{R}^{2}$ value is 0.92 or $92 \%$ which is also accepted. The perceptual image about the different brand of debit cards is represented in two-dimensional space. Multi-dimensional scaling technique can able to generate the different coordinates created on the basis of the responses. The coordinates created are represented in Figure 1 i.e. $\mathrm{X}$ co-ordinates and $\mathrm{Y}$ co-ordinates for SBI is $(-0.19,-1.42)$, for HDFC is $(1.42,-0.11)$, for ICICI is $(0.16,1.36)$ and for PNB is $(-1.39$, $0.17)$.

The Figure 1 shows the perceptual image which gives the pictorial representation of the different brands of debit cards. The above image shows that customers prefer primarily ICICI followed by HDFC, PNB and finally SBI debit card respectively.

\section{Concluding Observation}

It was observed through the factor analysis the importance of each variable for the decision of consumers to select any brands of debit cards. The relative importance of the variables can able to generate the factors. The first factor 'favorability' identified with acceptance, high level of discounts in brand of debit card, transaction in ATM, discounts on the basis of point system and international transaction. The second factor 'situation' explains the selection of a brand of debit card depends upon number of ATMs and distance of ATM from residence. The third factor 'recognition' explains the cash back reward system and unlimited transactions. The fourth factor 'biasness' explains the debit card is selected because of influence of family and most popular bank. The perceptual map created through the multi-dimensional scaling technique showed that customers are more inclined towards private sector banks rather than the public sector one. It gives the idea that people prefer the private banks especially ICICI the most. In the meanwhile other banks like HDFC, PNB and SBI should give better facilities in order to capture attention of the customers. Hence the research concludes that customer look after the 'favorability' in terms of benefits and 'situation' in terms of facilities factor while selecting any particular brand of debit card.

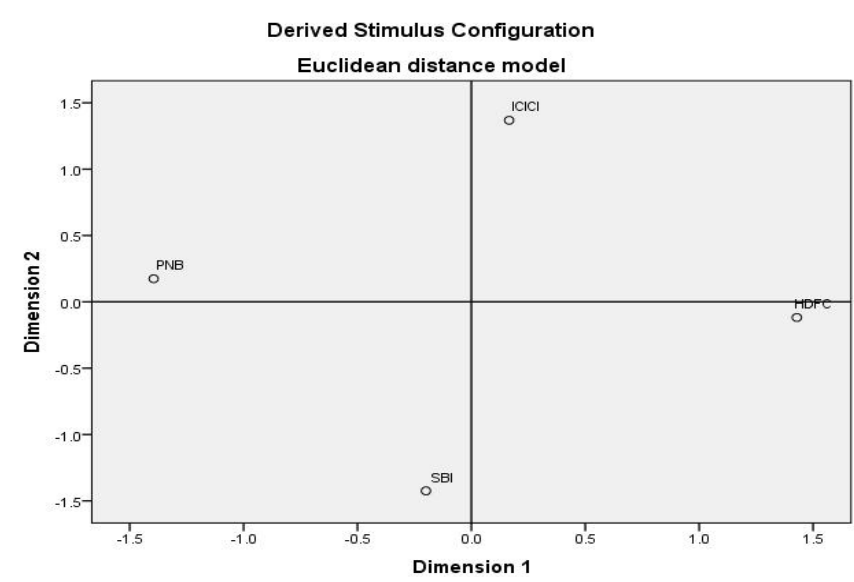

Figure 1: Pictorial representation of the different brands of debit cards.

\section{Limitations and Directions for Future Research}

As the research conducted in two cities of eastern part of India greater number of customers and more brand of debit cards can be considered for the further research. Here mostly young generation and mostly middle class respondents considered for the research work. Various categories of customers with upper class segment can be considered for the further research.

\section{References}

1. Caskey JP, Sellon Jr GH (1994) Is the Debit Card Revolution Finally Here? Economic Review - Federal Reserve Bank of Kansas City pp: 79-95.

2. Zinman J (2004) Why use debit instead of credit? Consumer choice in a trilliondollar market. Federal Reserve Bank of New York Staff Reports No.191.

3. Thaler RH (1999) Mental accounting matters. Journal of Behavioral Decision Making 12: 183-206.

4. Simon LM (2012) A Study on Customer Perception Towards Services Provided By Public Sector Bank and Private Sector Bank. Paripex - Indian Journal Of Research 1: 113-115.

5. Safeena R, Date H, Kammani A (2011) Internet Banking Adoption in an Emerging Economy: Indian Consumer's Perspective. International Arab Journal of e-Technology 2: 56-61.

6. Rama PP (2004) Product Innovation-A Suggestion from a Reader: KCC vs. ATM. Bank Quest April 75: 29-31.

7. Habib S (2012) Internet Banking in India Consumer Concerns and Bank Marketing Strategies. Research Journal of Management Sciences 1: 20-24.

8. Christopher G, Mike C, Visit L, Amy W (2006) A Logit Analysis of Electronic Banking in New Zealand. Int. J. Bank Market 24: 360-383. 
9. Chou DC, Chou AY (2000) A Guide to the Internet Revolution in Banking. Information Systems Management 17: 47-53.

10. Grabner-Krauter S, Faullant R (2008) Consumer acceptance of internet banking: the influence of internet trust. International Journal of bank marketing 26: $483-504$

11. Centeno C (2004) Adoption of Internet services in the Acceding and Candidate Countries, lessons from the Internet banking case. Telematics and Informatics 21: 293-315.

12. Durkin M, Jennings D, Mulholland G, Worthington S (2008) Key influencers and inhibitors on adoption of the Internet for banking. Journal of Retailing and Consumer Services15: 348-357.

13. Calisir F, Gumussoy CA (2008) Internet banking versus other banking channels: Young consumers' view. International Journal of Information Management 28 : 215-221.

14. Maenpa K, Kale SH, Kuusela H, Mesiranta N (2008) Consumer perceptions of Internet banking in Finland: The moderating role of familiarity. Journal of Retailing and Consumer Services 15: 266-276.

15. Sohail, SM, Shanmugham B (2003) E-banking and customer preferences in Malaysia: An empirical investigation. Information Sciences 150: 207-217.

16. Nilsson D (2007) Internet Banking and the Impact of Seller Support and Third Party. Journal of Internet Banking and Commerce 12: 1-9.

17. Plouffee CR, Yandenbosch M, Hulland J (2000) Why Smart cards have failed: looking to consumer and merchant reactions to a new payment technology. International Journal of Bank Marketing 18: 112-123.

18. Vora S and Gidwani R (1993) Plastic at a premium. Business India pp: 95

19. Carow Kenneth A, Staten AS (1999) Debit, credit, or cash: survey evidence on Gasoline Purchases. Journal of Economics and Business 51: 409-421.

20. Rysman M (2004) Competition between Networks: A Study of the Market for Yellow Pages. Review of Economic Studies 71: 483-512.

21. Hayashi F, Sullivan R, Weiner S (2003) A guide to the ATM and Debit Card Industry. Economic Review. Federal Reserve Bank of Kansas City pp: 1-44.

22. Barker T, Sekerkaya A (1992) Globalization of credit card usage: The case of a Developing Economy. International Journal of Bank Marketing 10: 27-31.

23. Mathur A, George P Moschis (1994) Use of Credit cards by older Americans. Journal of Services Marketing 8: 27-36.

24. Almeida M (1995) The Future's in Cards. Business India pp: 113-116.

25. Kaynak E (1995) Correlates of credit card acceptance and usage in an advanced developing Middle Eastern country. Journal of Services Marketing 9: $52-63$

26. Worthington S (1995) The Cashless Society. Internal Journal of Retail and Distribution Management 23: 31-40.
27. Worthington S (1996) Smart cards and retailers who stands to benefit? International Journal of Retail and Distribution Management 24: 27-34.

28. Gambhir AC (1989) Credit cards in India, Punjab National Bank Monthly Review 11: 413-420.

29. Leung WK, Lai KK (2001) Improving the quality of the credit authorization process. International Journal of Service Industry Management 12: 328-341.

30. Azhagaiah (2002) Credit creations through plastic money. Yojana 46: 33-34.

31. Lee J, Kwon Kyoung-Nan (2002) Consumers' use of credit cards: store credit card usage an alternative payment and financing medium. Journal Consumer Affairs Winter 36: 239-262.

32. Chakravarti S (2003) Theory of Credit Card Network: A Survey of The Literature. Review of Network Economics 2: 50-68.

33. Saha TR (2003) The Booming Credit Cards business of Indian Banking. The Management Accountant 38: 371-374

34. Easwar SA, Rawani NK (2004) Credit Card on a growth trajectory. Chartered Financial Analyst pp: 50-53.

35. Park HJ, Burns LD (2005) Fashion orientation credit card use, and compulsive buying. Journal of Consumer Marketing 22: 135-141.

36. Al-Alawi Al, Al Amer AM (2006) Young generation attitudes and awareness towards the implementation of smart card in Bahrain: An Exploratory study. Journal of computer science 2: 441-446.

37. Worthington S, Stewart D, Lu X (2007) The adoption and usage of credit cards by urban affluent consumers in china. International Journal of Bank Marketing 25: $238-252$.

38. Devlin FJ, Worthington S, Gerrand P (2007) An Analysis of main and subsidiary credit card holding and spending. Journal of Bank Marketing 25: 89-101.

39. Amin H, Pagar SJ (2008) Factors affecting the intentions of customers in Malaysia to use mobile phone credit card. Management Research News 31: 493-503.

40. Gan LL, Maysami R, Koh CH (2008) Singapore Credit cardholders: ownership usage patterns, and perceptions. Journal of Services Marketing 22: 267-279.

41. George P (1995) The Card Major Lead the Way. Business World p: 116.

42. Bhargava S (2004) Debit cards: A rule generation plastic money. Chartered Financial Analyst pp: 47-50.

43. Joshi G (1996) Variants in Plastic. Dalal Street Investment Journal 10: 50-51.

44. Maganty KK (1996) Changing dimension. Analyst pp: 95-96.

45. Radhakrishan R (1996) Debit Cards. PNB Monthly Review pp: 309-317.

46. Kaur M, Kaur K (2008) Development of plastic Cards Market: Past, future scenario in Indian Banks. Asia-Pacific Business Review 4: 62-74.

47. Manivannan P (2013) Plastic Money a way for cash Less Payment System Global Research Analysis 2: 10-12. 